\title{
The relation between broiler production management with its business analysis in Kediri district, East Java
}

\author{
Rico Anggriawan ${ }^{1)}$, and David Kurniawan*2) \\ 1) Faculty of Animal Science, University of Kahuripan Kediri, Jl. Soekarno Hatta, Ngeblek, \\ Pelem, Kec. Pare, Kediri, Jawa Timur, Indonesia 64213 \\ ${ }^{2)}$ Department of Poultry Product Processing, Community Collage of Putra Sang Fajar Blitar, \\ Jl. DR. Sutomo No.51, Bendogerit, Kec. Sananwetan, Kota Blitar, Jawa Timur, Indonesia \\ 66133
}

Submitted: 21 October 2019, Accepted: 06 September 2020

\begin{abstract}
This study was conducted in April to August 2019 to determine the relation between broilers' production management with its business analysis in Kediri district, East Java. The research using survey methods. The questionnaire was used as a data collection tool, which was carried out by interviews and field observations. Determination of location and respondent uses purposive sampling method and selects 25 farmers. Production management indicators consist of five categories; breed, feeding, housing system, maintenance, and health. Business analysis indicators consist of R/C ratio, Break Event Point (BEP), and Payback Period (PP. Data analysis uses descriptive analysis and statistical analysis of the Structural Equation Modeling (SEM) method using the Partial Least Square (PLS) program. The results showed that farmers had implemented production management well. Broiler partnership farm is a profitable business. The value of Revenue Cost ratio was 1.45 and with the Payback Period for 2.97 years. Production management of broiler farms has a positive and significant effect on its business analysis.
\end{abstract}

Keywords: Production management; Breakeven point; R/C ratio; PLS

*Corresponding Author: davidkurniawan@kahuripan.ac.id 


\section{INTRODUCTION}

Consumer demand for broiler overcame other animal protein in Indonesia. The consumption of broiler increased 11.22 percent from $5.11 \mathrm{~kg}$ per capita in 2016 to $5.68 \mathrm{~kg}$ per capita in 2017. In Indonesia, broiler chicken production contributed up to 2.0 million tons or 59.03 percent of the total meat production in 2017. Total Meat production in 2017 increased up to 3.32 percent compared to the previous year, and broilers contributed 7.42 percent of it (Animal Husbandry and Animal Health Statistics, 2018). With the high demand for broiler, it not surprising if the broiler breeding business in Indonesia is growing rapidly. The partnership system in Indonesia is regulated through Regulation of the Minister of Agriculture of the Republic of Indonesia Number 13 / PERMENTAN / PK.240 / 5/2017 concerning Husbandry Business Partnerships. The profit-sharing partnership system is a business collaboration system between farmers and a livestock company. The distribution of profits in the broiler business is determined based on the agreement of both parties. Raut et al. (2017) stated that broiler farms are profitable businesses and the success of poultry farming businesses depends on high productivity and low mortality. This is closely related to the management system of broiler production.

Broiler chicken partnership in the Puncu subdistrict, Kediri Regency is a private company that carries out an independent plasma-core partnership pattern for the maintenance of broiler. In this partnership scheme, farmers provided pens, equipment, and labor. On the other hand, Farmers received regular guidance on production management, include housing systems, brooding period, feed management, and disease control from the company, and the company also provided Day Old Chicks (DOC), feed, medicines, and vaccines. The advantage of the partnership system is the responsibility of both parties. The weakness of the partnership system is the high potential of dishonesty related to the costs incurred from both sides. The farmers will bear a loss if the harvesting price is below the cost of production (Amam et al. 2019). Firdaus and Komalasari (2010) reported that the integrated broiler business with feed mills was more resistant to the fluctuating price of chicken and DOC. Haryuni and Fanani (2017) stated that DOC price on the partnership system was $9.52 \%$ more expensive than the independent system. The price of feed on the independent system is cheaper around Rp. $1.000 / \mathrm{kg}$ compared to the partnership system. The result of the economic analysis shows that the broiler business is profitable (Raut et al. 2017; Febrianto et al. 2018). Based on the previous description, it is necessary to conduct a study of business analysis and the relationship between broiler's production management in Kediri District, East Java.

\section{MATERIALS AND METHODS}

The study was conducted in AprilAugust 2019 in Puncu Subdistrict, Kediri Regency. The research respondents were 15 broiler partnership farmers who have a population of 3000-5000 broilers. The study utilized purposive sampling as the sampling technique and the survey method. Data collection was also carried out by observation, which is taking data by systematically recording the results of observations of the events investigated during the study. Primary data obtained through interviews with structured questionnaire media. Secondary data obtained through data collection by looking at the document notes related to research as supporting data. Statistical data analysis uses the Partial Least Square (PLS) analysis method, which is an alternative method of Structural Equation Modeling (SEM) based on Variance. Research variables include production management and business feasibility analysis. Production management includes seed management, feed management, housing management, health 
management, and maintenance management. This production management is associated with a business feasibility analysis consisting of Break Event Points (BEP), R / C Ratio, and Payback Period (PP).

a. Break-Even Point is a situation where a business does not lose or profit. Systematically as follows:

BEP Price $=\frac{\text { Total Cost Production }}{\text { revenue }}$

BEP Unit $=\frac{\text { Total cost }}{\text { Product price }}$

b. Revenue Cost Ratio ( $\mathrm{R} / \mathrm{C}$ ratio) is a comparison between revenue and total cost. Systematically as follows:

$\mathrm{R} / \mathrm{C}$ ratio $=\frac{\text { Revenue }}{\text { Total Cost }}$

Note:

If $\mathrm{R} / \mathrm{C}>1$, worth for business.

If $\mathrm{R} / \mathrm{C}<1$, unfit for business.

c. Payback Periode is the period time required to pay for all costs incurred in investing in a business. Systematically as follows:

Note:

$\mathrm{PP}=\frac{\text { Value of invest }}{\text { Net Cash Flow }} \mathrm{X} 1$ year

If the value of the investment is shorter than the maximum payback period, then the investment proposal can be accepted.

\section{RESULTS AND DISCUSSION Production Management}

Broiler chicken production management system consists of five indicators, namely Day Old Chicks (DOC), maintenance, housing, feeding, and disease control. A good quality DOC has high meat production and low feed conversion. There are three groups of DOC, namely silver, gold, and platinum. Broiler breeds in broiler farms depend on core partnerships. The percentage of mortality and morbidity of broiler chickens (DOC) mostly occur at the age of 1-7 days. The maintenance system of broiler chicken includes sanitation (spraying, dipping, personal protective equipment), the long maintenance phase of the brooding, cleaning the pen and the temperature of the pen, maintenance temperature in the starter and finisher phases. Broiler chicken farms apply the same farm management to each plasma, intending to obtain good chicken quality and maintenance efficiency.

Broiler farm is located in the rice fields and far from residential areas. The construction of an open house that is built for the broiler breeding business is in the form of a semi-permanent stage housing that is relatively inexpensive for farmers. Proper housing construction can be found in broiler farms with asbestos roofs or leaves of sugar cane plants which are dried as the roof. Ismail et al. (2013) reported that different types of enclosures showed the same level of business viability seen from the $\mathrm{R} / \mathrm{C}$ ratio value. Closed house farms are more profitable compare to an opened house with the same number of livestock populations.

Management of broiler feeding includes the intensity of feeding, the suitability of protein content, and feed ratio from the starter to the finisher phase. The intensity of feeding given in broilers is generally done two to three times per day. Appropriate levels of protein feed starter phase range from 22$23 \%$. The suitability of finisher phase protein levels in each farm ranges from 18 $20 \%$, depending on the feed rations used in feeding. Starter feed diets in broiler farms use core processed food rations so that they have an appropriate protein content of 18$19 \%$, while feed rations in some broiler farms use commercial feed or manufacturer feed.

Broiler chicken disease control systems include personnel, vaccination programs, provision of vitamins, and medicines. Disease control by a medical personnel (veterinarian) is important in broiler farms. There are some vaccination programs for broilers including Newcastle Disease (ND), avian influenza (AI), infectious bronchitis (IB), and Gumboro done periodically through subcutaneous injection, eye drops, and drinking water. Moreover, Broiler chicken medicines such 
as antibiotics, vitamins, and vaccines are needed to prevent or treat chickens from diseases and important to support the success of broiler farms.

\section{Business Feasibility Analysis}

The result of business analysis calculation from the broiler chicken partnership pattern in Puncu District, Kediri Regency can be seen in Table1. Based on the calculation results of the broiler partnership business analysis shows that the broiler farm business with an average population of 3970 chickens is feasible to run. The total revenue from the broiler partnership business is Rp. 40,629 with a total production cost of Rp. 28,000 . Primaditya et al. (2015) stated that boiler farming income is influenced by the scale of the business and the number of costs incurred. An $\mathrm{R} / \mathrm{C}$ ratio of 1.45 indicates that every Rp. 1000 costs incurred for broiler production activities will generate revenue of Rp. 1450 or the profit gained is Rp. 450 .

BEP selling price from the broiler partnership of Rp. 12,776 which means that with the selling price, the farmer does not experience a loss or gain a profit. The BEP value of the unit was obtained $6,036 \mathrm{~kg}$ for 3970 broilers which means breeders would break even in the broiler partnership if the average harvest weight per chicken was 1.52 $\mathrm{kg}$. The payback period of the broiler partnership business is 2.97 years, which means the investment value of the business will be able to return after running the business for 2.97 months or 2-3 periods of broiler partnership production. Similar results were reported by Febrianto et al. (2018) that the broiler farming business is a profitable and feasible business activity to be continued with an $\mathrm{R} / \mathrm{C}$ ratio of 1.11 .

Table 1. Analysis of broiler farm partnership.

\begin{tabular}{lc}
\hline Business Analysis & Mean \\
\hline Populatin (bird) & 3970 \\
Total revenue (Rp/bird) & 40.629 \\
Total cost production (Rp/bird) & 28.001 \\
R/C ratio & 1.45 \\
BEP price (Rp/kg) & 12.776 \\
BEP unit (kg/period) & 6.036 \\
PP (years) & 2.97 \\
\hline
\end{tabular}

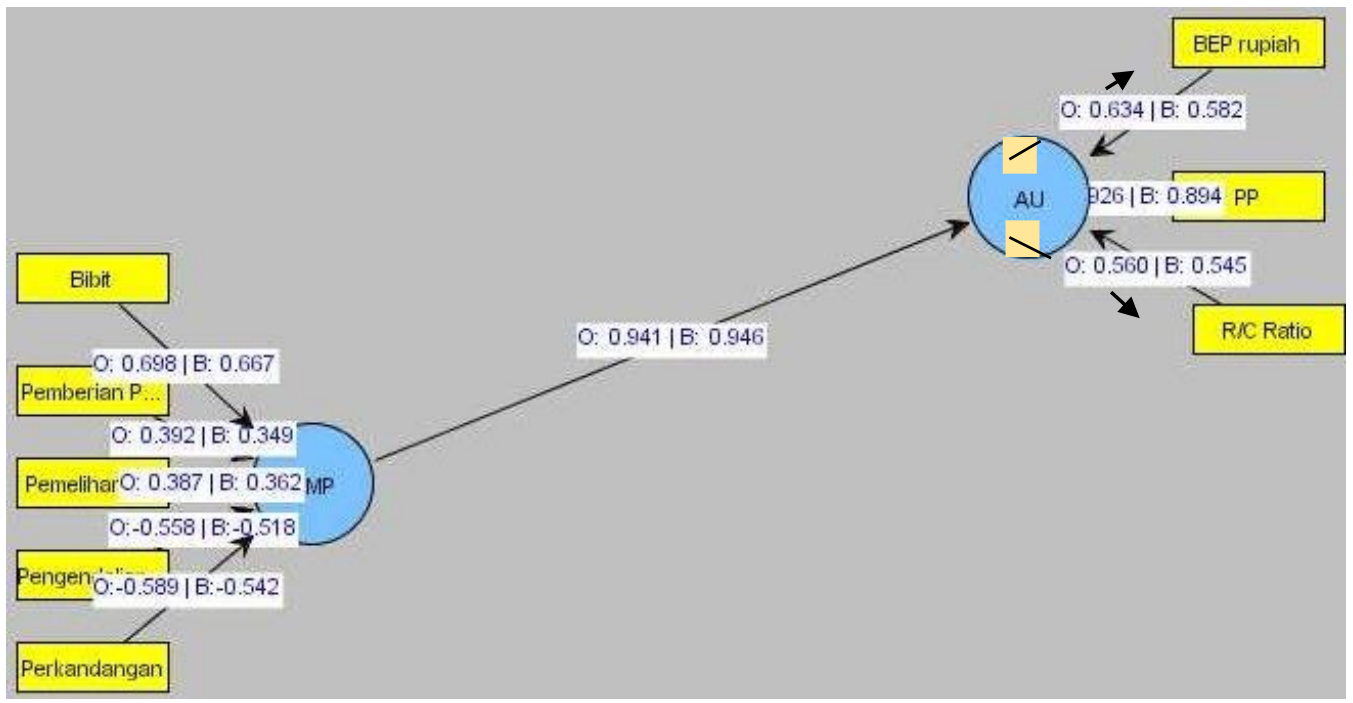

Figure 1. The result Inner Model (Bootstrapping Sample Estimate)

Note:

$\begin{array}{llll}\text { MP } & =\text { Production management system } & \text { Pengend } & =\text { Disease control } \\ \text { Pemberi } & =\text { Feeding } & \text { AU } & =\text { Business analysis } \\ \text { Pemeliharan } & =\text { Maintenance } & & \end{array}$


Table 2. Inner Weights (Mean, Standard Deviation, T-Value)

\begin{tabular}{lcccc}
\hline Relationship & $\begin{array}{c}\text { Original sample } \\
\text { estimate }\end{array}$ & $\begin{array}{c}\text { Mean of } \\
\text { Subsamples }\end{array}$ & $\begin{array}{c}\text { Standard } \\
\text { deviation }\end{array}$ & T Statistic \\
\hline $\begin{array}{l}\text { Production } \\
\text { Management => } \\
\text { Business Analysis }\end{array}$ & 0,941 & 0,946 & 0,017 & 54,690 \\
\hline
\end{tabular}

\section{Relationship between production management and business feasibility}

Partial least square (PLS) analysis is used to determine the relationship between product management and the feasibility analysis of the broiler partnership business. PLS analysis is carried out through two stages, first is testing the inner model or structural model and second is testing the outer model analysis. The structural model or inner model is evaluated by looking at the percentage of variance that is explained by looking at the magnitude of the coefficient of the structural path. The stability of this estimate is evaluated using the T-Statistic test, indicating that the variables that have significant influence are production management and business feasibility analysis. The results of the inner model of production management relationships and business feasibility analysis are shown in the structural model in Figure 1.

Modeling Figure 1 shows that the production management system for broilers indicators consists of seedlings, feeding, maintenance, disease control, and housing. Business analysis is an analysis that is influenced by production variables, including three indicators; BEP (price), PP, and $\mathrm{R} / \mathrm{C}$ ratio. $\mathrm{BEP}$ (unit) is a factor that does not significantly influence production so it does not appear on the Inner Model. Testing the inner model can be done by looking at the significance of the effect of the production management system on business analysis by looking at the value of the parameter coefficient and the significance value of the T-statistic. The results of the testing of the parameter coefficient values and the significance value of the T-statistics are presented in Table 2.
The results of the inner model testing show that the magnitude of the parametric coefficient of production management on business analysis is 0.941 , which means that there is influence between variables. The higher the production management, the higher the business feasibility analysis. Data analysis shows a T-statistic value $\geq$ of 1.96 which is 54.690. This shows significant results (T-table significant $5 \%=1.96$ ) because the T-statistic value is greater than T-table that is equal to 1.96. Rahadi et al. (2014) reported that production management of male laying hens has a positive impact on business viability. This is similar Sekarwangi et al. (2015) statement that the production management of quail laying also has a positive impact on business feasibility.

Convergent validity (convergent validity) is the value of the loading factor on latent variables with their indicators. The loading factor is the path coefficient that connects the latent variable with the indicator. The validity indicator can be seen from the loading factor and T-statistic values. The loading factor value is greater than 0.5 and the T-statistic value is greater than 1.96 indicating that the indicator is valid. The results of the outer model analysis of the relationship between product management and business analysis are shown in Table 3.

Breed indicators, BEP (price), PP, and $\mathrm{R} / \mathrm{C}$ ratio in Table 3 have an outer loading value of more than 0.50 . These indicators have good validity (convergent validity), so it can precisely measure the latent variable. The indicator of feeding and maintenance are in the range of $0.1-0.4$ so that both of these variables can still be 
tolerated because they are still in the development stage. Disease control and housing indicators are eliminated because these indicators have a loading value of less than 0.5 , which means that these indicators have poor convergent validity. These indicators are not appropriate to measure latent variables.

Table 3. Outer loading production management and business analysis of broiler chicken.

\begin{tabular}{|c|c|c|c|c|c|}
\hline Contruct & Indicator & $\begin{array}{c}\text { Original sample } \\
\text { estimate }\end{array}$ & $\begin{array}{c}\text { Mean of sub- } \\
\text { samples }\end{array}$ & $\begin{array}{l}\text { Standard } \\
\text { deviation }\end{array}$ & $\begin{array}{c}T- \\
\text { Statistic }\end{array}$ \\
\hline \multirow{5}{*}{$\begin{array}{l}\text { Production } \\
\text { management }\end{array}$} & Breed & 0,698 & 0,667 & 0,247 & 2,826 \\
\hline & Feeding & 0,392 & 0,349 & 0,215 & 1,824 \\
\hline & Maintanance & 0.387 & 0.362 & 0.223 & 1.739 \\
\hline & $\begin{array}{l}\text { Disease } \\
\text { control }\end{array}$ & -0.558 & -0.518 & 0.238 & 2.346 \\
\hline & Housing & -0.589 & -0.542 & 0.306 & 1.922 \\
\hline \multirow{3}{*}{$\begin{array}{c}\text { Business } \\
\text { analysis }\end{array}$} & $\mathrm{BEP}$ (price) & 0,634 & 0,582 & 0,235 & 2,699 \\
\hline & $\mathrm{PP}$ & 0,926 & 0,894 & 0,372 & 2,488 \\
\hline & $\mathrm{R} / \mathrm{C}$ ratio & 0.560 & 0.545 & 0,223 & 2,514 \\
\hline
\end{tabular}

Based on these results it shows that product management has a positive relationship with business feasibility. Cahyana et al. (2016) reported that independent management of broiler production has a positive relationship with business feasibility including the use of one breed, feeding and drinking, cage cleaning, and mortality rates. Ritonga et al. (2017) reported that a positive relationship between production management and business analysis was also found in goat farms, namely maintenance and feed management factors.

\section{CONCLUSION}

Broiler's production management with a partnership system in the Puncu subdistrict, Kediri District has been well applied by farmers. Broiler breeding business with a partnership system is a feasible business to run based on business analysis with a population of 3970 tails with a production $\mathrm{BEP}$ value of $6,036 \mathrm{~kg}$, a price BEP of Rp. 12,776 / kg, R/C ratio of 1.45 , and PP value of 2.97 years. There is a relationship between production management and the feasibility analysis of the broiler partnership business. The influential management component is the DOC.

\section{REFERENCES}

Amam, A., Fanani, Z., Hartono, B., \& Nugroho, B. A. (2019). Pengembangan usaha ternak ayam pedaging sistem kemitraan bagi hasil berdasarkan aksesibilitas peternak terhadap sumber daya. Jurnal Ilmu Dan Teknologi Peternakan Tropis, 6(2), 146-153. https://doi.org/10.33772/jitro.v6i2.5578

Cahyana, N. A. D. A., Lamid, M., \& Soeharsono. (2016). Model hubungan manajemen proses produksi terhadap analisis usaha peternakan ayam broiler pola mandiri di kecamatan paciran kabupaten lamongan. Jurnal Agro Veteriner, 4(2), 144-148.

Febrianto, N., Putritamara, J. A., \& Hartono, B. (2019). analisis kelayakan usaha peternakan broiler di Kabupaten Malang. Agriekonomika, 7(2), 168175. https://doi.org/10.21107/agrieko nomika.v7i2.4451

Firdaus, M., \& Komalasari, L. (2010). Feasibility analyses of integrated broiler production. Media Peternakan, 33(3), 182-188. https://doi.org/10.53 98/medpet.2010.33.3.182

Haryuni, N., \& Fanani, Z. (2017). Study of Feasibility on broiler business development. Journal of Development Research, 1(2), 63-67. https://doi.org/ 10.28926/jdr.v1i2.25 
Ismail, I., Utami, H. D., \& Hartono, B. (2014). Analisa ekonomi usaha peternakan broiler yang menggunakan dua tipe kandang berbeda. Jurnal Ilmu-Ilmu Peternakan, 23(3), 11-16.

Rahadi, U. S. E., Harijani, N., \& Soepranianondo, K. (2014). Hubungan sistem manajemen proses produksi terhadap analisa usaha peternakan ayam petelur jantan di Kabupaten Malang. Jurnal Agro Veteriner, 3(1), 24-32.

Raut, S. D., Malave, D. B., \& Gore, S. T. (2017). Financial feasibility of investment in Broiler poultry units in Raigad district of Maharashtra. International Research Journal of Agricultural Economics And Statistics, 8(1), 170-175. https://doi.org/10.157 40/HAS/IRJAES/8.1/170-175

Ritonga, M. Z., Soepranianondo, K., \& Hidanah, S. (2017). Hubungan manajemen produksi terhadap análisis usaha peternakan kambing di kecamatan Candi kabupaten Sidoarjo. Jurnal Agro Veteriner, 5(2), 200-207. Santos, N. C., Figueira-Coelho, J., MartinsSilva, J., \& Saldanha, C. (2003). Multidisciplinary utilization of dimethyl sulfoxide: pharmacological, cellular, and molecular aspects. Biochemical Pharmacology, 65(7), 1035-1041. https://doi.org/10.1016/ S0006-2952(03)00002-9

Sekarwangi, N., Hidanah, S., \& Supranianondo, K. (2015). Hubungan sistem manajemen proses produksi terhadap kelayakan usaha peternakan puyuh petelur di kabupaten kediri. Jurnal Agro Veteriner, 4(1), 28-33.

Suzuki, T., Komada, H., Takai, R., Arii, K., \& Kozima, T. T. (1995). Relation between Toxicity of Cryoprotectant DMSO and Its Concentration in Several Fish Embryos. Fisheries Science, 61(2), 193-197. https://doi. org/10.2331/fishsci.61.193 